\title{
The Concept of Risk Capital and Its Application in Non-Financial Companies: A Sustainable Dimension
}

\author{
Monika Wieczorek-Kosmala \\ Department of Corporate Finance and Insurance, Faculty of Finance and Insurance, University of Economics \\ in Katowice, 40-287 Katowice, Poland; m.wieczorek-kosmala@ue.katowice.pl; Tel.: +48-32-257-77-51
}

Received: 30 December 2018; Accepted: 5 February 2019; Published: 9 February 2019

\begin{abstract}
The prime purpose of this paper is to explain the concept of risk capital and advocate for its implementation in the management of non-financial companies. The paper is kept in the discursive tone, as the problem is new, and it first requires to establish the conceptual framework for further empirical considerations. With reference to the origins of the concept of risk capital (related to its understanding in financial institutions), the paper discusses the utility of risk capital for the management of risk in non-financial companies, with the recognition of the sustainable dimension of risk capital. The discussion is framed within the corporate finance approach. In the applicative dimension, the paper identifies the universe of the sources of risk capital and proposes a taxonomy of these sources. It considers both the well-established traditional sources, as well as the state-of-the-art solutions that are in the early stages of their adoption for the needs of corporate end-users. The conclusions address the possible areas of tensions and of the inclusion of risk capital in the decision-making process, as well as the areas of further empirical research within.
\end{abstract}

Keywords: risk capital; risk management; risk outcomes; sustainable risk management; alternative risk transfer; risk retention

\section{Introduction}

Contemporary companies operate in the unprecedented dynamics of the environment, facing the challenges and threats imposed by the variety of endogenous and exogenous factors. In addition, the business entities are expected to perform in a way that conforms to the idea of sustainable development. Companies are expected to follow the triple-bottom-line concept (people, planet, and profit) on their route to the achievement of sustainable development goals [1]. This challenge calls for a modification of various aspects of a company's performance. To some extent, companies implement the solutions that allow it to conform to the features of a 'sustainable company' by integrating adequate self-regulation into their business models [2]. The existing empirical research proved that still for many companies the ethical obligations or genuine intrinsic altruism is less important, in comparison to the reputational dimension of socially responsible performance. However, being socially responsible still remains an ambiguous and elusive concept in numerous dimensions [3]. Thus, the concept of sustainable performance needs to be instrumentalized, and there is a noticeable cognitive gap within.

This paper contributes to the debate on sustainable corporate performance, by referring to the importance and applicative dimension of risk management. Lessen et al. [4] placed risk management among one of the relevant 'sustainability mechanisms' that could be implemented on an organizational level. The execution of well-designed risk management process, with adequately implemented risk treatment strategies, is very important to the ability to resist shocks, as well as to respond properly. Many times, we have witnessed the scale of the consequences of risk that were amplified by the failures of risk management (with respect to the consequences of both man-made and natural disasters). The global financial crisis of 2007-2009, the Deep Water Horizon oil spill or Fukushima nuclear 
disaster stand as recent examples of the potential scale of the damage caused in environmental and socio-economic dimensions. In this regard, we shall refer to the currently advocated concept of sustainable risk management, that postulates the greater awareness of the 'socially responsible' execution of risk identification, analysis, and treatment $[4,5]$.

The above considerations reflect the motivation behind this paper which is to draw attention to the company's preparedness for the consequences of endogenous and exogenous shocks. The discussion is framed within the corporate finance assumptions: The paper refers to a company's ability to sustain the negative outcomes of risk, measurable by unforeseen and undesired cash flow volatility.

In this regard, the primary purpose of this paper is to explain the concept of risk capital and advocate for its implementation in the management of risk of non-financial companies. The concept of risk capital originates from financial institutions and refers to the explicit financial preparedness for the consequences of the unexpected loss (as the risk outcomes). Accordingly, in the instrumental dimension, numerous academic works discussed the elements of the financial institutions' 'capital adequacy' embedded in regulatory frameworks for the banking and insurance sector [6-10]. As noted by Culp ([11], p. 801), however, although risk capital and the problem of risk capital allocation is relevant primarily for financial institutions, 'risk capital is a conceptually important ingredient of any complete risk management discussion ( ... )' and further 'risk capital does sometimes matter to nonfinancial corporates. For these reasons, it is worth some attention here'. Up to date, the concept of risk capital is relatively scarcely addressed in the literature with reference to the non-financial companies. The Culp [11] considerations were preceded by works by Shimpi [12], followed by some dispute by Doherty [13] and O'Brien [14]. To fill in this gap, this paper defines the risk capital with respect to the non-financial companies and further identifies the sources of risk capital available for non-financial companies.

This paper is kept in the discursive tone, as the discussion on risk capital in non-financial companies is in its early stage. Thus, there are virtually no empirical studies that address the measurement or the implementation of risk capital in non-financial companies. In this regard, this paper is a relevant contribution to the existing literature, as it discusses the utility of risk capital and the routes of its possible allocation in non-financial companies. This seems essential for the establishment of the comprehensive and unequivocal conceptual framework that could be further applied in empirical studies within. In the theoretical dimension, the paper also contributes to the discussion on the frameworks of 'sustainable corporate finance' and 'sustainable risk management'.

A second relevant contribution of this paper is the identification of the sources of risk capital. These sources should be associated with the mechanisms or solutions that allow a company to obtain the injection of funds, as assigned for counterbalancing the financially measurable negative outcomes of risk. The sources of risk capital are identified in this paper. Moreover, the proposition of the taxonomy of the sources of risk capital is formulated, with the distinction between the traditional and alternative ones. This dichotomic classification echoes the evolution of the concept of risk management-from a single-risk oriented concept focused on the transfer of risk, to a more mature holistic approach that postulates the integration of risk management with all areas of decision-making $[15,16]$. Traditional sources of risk capital are relatively largely discussed in the academic literature, and their implementation is well established in companies' performance (e.g., insurance or derivative contracts). However, the alternative sources of risk capital are scarcely discussed in the context of their applicability to non-financial companies (or corporate end-users). In this regard, this paper contributes to the popularization of the new, alternative solutions that have recently become implementable in corporate risk management strategies.

The remainder of this paper is structured as follows. The Section 2 outlines the concept of risk capital in non-financial companies, with reference to its origins and the relationship with the elements of the risk management process. The discussion also refers to a sustainable dimension of the concept of risk capital. The Section 3 adopts an instrumental approach and provides an overview of the sources of risk capital available for non-financial companies, with a distinction of the characteristic features of these sources (that is executed for the proposition of the taxonomy of risk capital sources). The Section 4 
provides conclusions and final remarks, as addressed to the possible areas of tensions and limitations of risk capital implementation and the possible design of further empirical investigations.

\section{The Concept of Risk Capital in A Non-Financial Company}

\subsection{The Origins of the Concept}

The concept of risk capital is well established in financial institutions and is related to the specifics of their performance. Financial institutions (both banks and insurance companies) are regarded as the institutions of public trust, and any disturbances in their performance may cause repercussions in the functioning of the financial system and even initiate economic downturn [17]. In the insurance system, public trust is related to the aleatory and promissory nature of insurance contracts [18] (p. 241), whereas in the banking system it is related to depositors' confidence on the accessibility of their savings [19] (p. 681). These considerations are substantial for the regulatory framework of financial institutions (the Basel Accords in the Banking system and Solvency rules in the insurance system), with the requirement of 'capital adequacy', accompanied by the proper approach to risk management [6-10]. In the contemporary globalized world, the problem grows in importance: The free flow of capital has the potential to boost the contagion effect globally, as was observed during the recent global financial crisis of 2007-2009 [20,21].

The discussion on the rationale behind the concept of risk capital in 'financial firms' (for financing, capital budgeting, and risk management needs) was initiated in 1993 in the seminal work by Merton and Perold [22]. According to Merton and Perold, financing firms are distinguished by three relevant features (that reflect the concern of public trust): (a) Customers can be the major liability holders (policyholders or depositors are customers and liability holders at the same time); (b) limited opaqueness to customers and investors (the problem of information disclosure; if disclosed-with a lag), and (c) profitability highly sensitive to the cost of capital (as financial firms operate in competitive financial markets) [22] (pp. 16-17). Merton and Perold argued that apart from regulatory capital (that corresponds with the concept of capital adequacy and reflects the capital needed to meet the regulatory requirements) and cash capital (capital required to execute transactions, as working capital), financial institutions should measure and manage risk capital. Risk capital was defined by Merton and Perold [22] (p. 17) as 'the smallest amount that can be invested to insure the value of the firm's net assets against a loss in value relative to the risk-free investment of those net assets' (Net assets were defined as gross assets minus customer liabilities [22] (p. 17). However, Culp [11] (pp. 807-808) explains that for Merton and Perold risk capital is the equivalent of the insurance of net assets $(A N)$, and for any given time $t$ net assets have a value of

$$
A N(t)=A(t)-L(t)
$$

where $A(t)$ are the firm's gross assets and $L(t)$ are firm's liabilities or contracts offered on a risk-free basis. Accordingly, risk capital is an insurance or option contract with the following pay-off at time $t+T$.

$$
\max \left\{S_{A N(t+T)} ; 0\right\}
$$

where $S_{A N(t+T)}$ reflects a shortfall of net assets.

The concept was further adjusted for financial institutions with reference to the ability to absorb the expected and unexpected losses. The expected losses are related to the typical operating activity of financial institution and, thus, should be explicitly considered while determining the capital adequacy (as the reserves for expected losses). The unexpected losses are defined as the losses that exceeded the expected losses ([23], p. 7; [24], p. 5; [25], p. 216). In this context, risk capital (RC) could be defined as funds that are needed to safeguard the unexpected losses and reflects a cushion against the unexpected losses [11] (pp. 806-807):

$$
R C=L-E L
$$


where $L$ stands for the total losses, $E L$ stands for expected losses at a given confidence level. Figure 1 highlights the understanding of risk capital in this context and reflects VaR (Value at Risk) - the measure of risk capital, widely applied in financial institutions. The measurement of VaR (Value at Risk) was originated by J.P. Morgan (as RiskMetrics ${ }^{\mathrm{TM}}$ ). See: ([26], p. iii; [27], p. 29; [28], pp. 128-129).

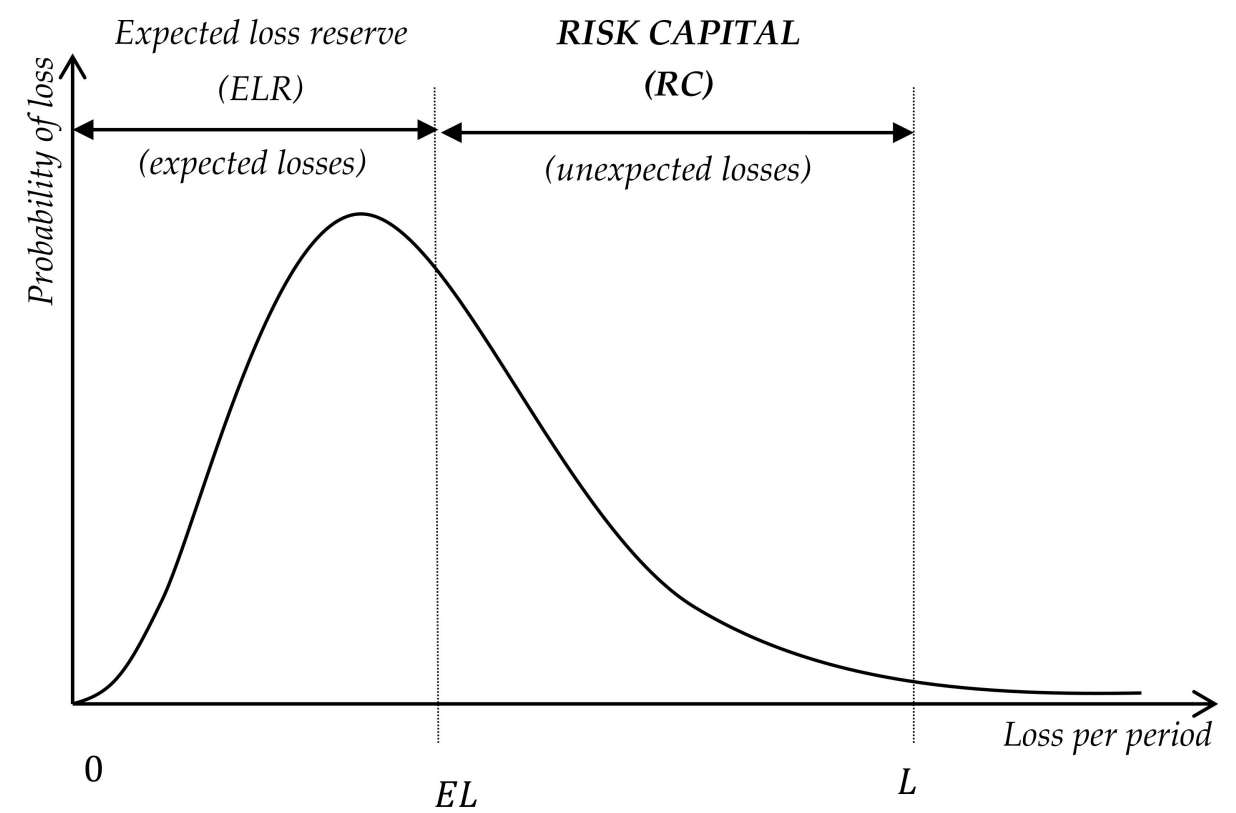

Figure 1. Risk capital and the distribution of potential losses per period ([11], p. 806; [24], p. 5; [25], p. 216; [23], p. 7).

The idea of risk capital outlined in Figure 1 emphasizes the understanding of risk capital as a cushion against the unexpected losses. As noted by Culp [11] (p. 801), although risk capital and the problem of risk capital allocation is relevant, primarily, for financial institutions, it is also conceptually relevant for non-financial companies within the enhancement of the complexity of risk management. However, the translation of the utility of risk capital for non-financial companies, with the exemplification of its sources, is rare in the academic debate. In a comprehensive model dimension, the problem was discussed by P. Shimpi [29,30] and C. Culp [11], with a commentary by Doherty [13]. This discussion is summarized briefly below, with a focus on the components of capital structure and risk capital structure.

The inclusion of risk capital to the capital structure considerations in a way applicable for non-financial companies was first addressed by Shimpi [12,29,30]. In particular, Shimpi distinguished between the (a) operating capital, (b) risk capital, and (c) signaling capital. According to Shimpi, the operating capital reflects the funds that a company needs for its operating performance, if not affected by negative risk outcomes. The risk capital is reflected by the additional stock of funds that are assigned for the coverage of the consequences of risk occurrence (buffering function). Finally, the signaling capital is reflected by additional funds that are held for signaling purposes (as postulated by signaling theory developed by Ross [31]). Shimpi argued that risk capital, as an additional stream of funds assigned for covering the consequences of risk, is reflected in a company by the value of insurance policies or derivative contracts. In this regard, Shimpi associated a company's risk capital with the funds that are obtainable through risk transfer (as insurance and derivatives are regarded as risk transfer mechanisms). A complex framework of the concept of risk capital was considered by Shimpi in the shape of 'the insurative model', where the risk capital sourced from insurance and derivatives was placed as an additional element of a company's capital structure, within the traditional 
balance-sheet debt and equity mix ([29], pp. 33-34; 302-303). Accordingly, the insurative model defines a company's capital structure as follows:

$$
\begin{gathered}
C=O C+R C \\
\text { and } O C=E+D \\
R C=T \\
\text { thus } C=E+D+T
\end{gathered}
$$

where $C$ denotes a company's capital, $O C$ denotes operating capital, $R C$ denotes risk capital, $E$ denotes equity, $D$ denotes debt, $T$ denotes risk transfer instruments (insurance or derivatives).

It should be noted that Shimpi's proposal (as outlined in the insurative model) differs from Merton's and Perold's approach. Shimpi considered risk capital as an additional element of capital structure, whereas Merton and Perold addressed risk capital as an element of the existing capital structure [13] Thus, in Merton's and Perold's concept (as explained by Doherty [12]) both equity or debt could be allocated as risk capital. This discussion leads to the conclusion that some sources of risk capital (available for non-financial companies) go beyond the balance sheet perspective (equity and debt). Thus, we may distinguish between balance-sheet and off-balance sheet (hidden) risk capital. This distinction was highlighted by Culp [32,33]. Similar to Shimpi, Culp considered risk capital as funds held in excess of a company's operating needs, in a buffering function. The funds held in excess (as risk capital) could be, thus, sourced from equity or debt, as well as from additional 'hidden' sources (e.g., insurance or derivatives). Accordingly, the model structure of risk capital is

$$
R C=R C_{E}+R C_{D}+R C_{C T}
$$

where $R C_{E}$ and $R C_{D}$ reflect the sources of risk capital captured in the balance sheet as equity or debt, and $R C_{C T}$ reflects the contingency funding that constitutes the off-balance sheet (hidden) risk capital. The contingency funding $\left(R C_{C T}\right)$ embraces the capital allocation contingent upon the occurrence of risk. In this regard, the examples of contingency funding are insurance or derivatives in hedging function. Balance-sheet captured risk capital $\left(R C_{E}\right.$ and $\left.R C_{D}\right)$ reflect funds allocated to retain the negative risk outcomes.

Driving upon the existing literature concepts, risk capital in a non-financial company should be associated with funds that are allocated in the buffering function. Thus, risk capital could be defined as funds assigned to cover the negative risk outcomes that a company may face. In other words, risk capital is held or acquired to absorb financial losses and, thus, helps to safeguard a company's financial position. The decisions on risk capital allocation are, thus, substantial in a company's risk management process.

\subsection{The Need of Risk Capital: Risk Management Perspective}

The concept of risk management is dated back to 1950s, and at that time it was perceived in a narrow context, with a focus on the risky events that could be insured. In the 1970s and 1980s, the risk management discipline was dominated by the consideration of the application of derivatives [34-36]. In the mid-1990s the risk management concept evolved toward a holistic dimension, which postulated the management of the portfolio of risks across the whole enterprise. At that time, the term ERM (enterprise risk management) was coined, to distinguish between the broadened and strategic approach to risk management and the narrowed one (often referred to as TRM 9traditional risk management)) $[15,16]$. In the ERM concept, the application of the usual risk management tools is performed in a systematic way, as an ongoing concern [37]. In general, risk management could be defined as a process that is designed to cope with risk in an organization. The process begins with the identification of risk, followed by risk assessment, decisions about risk treatment and the communication and constant review of the process [38,39]. Identification of risk requires the 
consideration of various exogenous and endogenous factors that could threaten the organization's performance. Risk assessment embraces the assessment of probability (frequency of occurrence) and severity (the consequences, as the possible damage caused) of each of the identified risks [40]. The treatment of risk is related with the implementation of risk management tools and techniques. The spectrum of the possible techniques is nicely summarized in the Hopkin's proposal [41], who distinguished between the decision to (i) tolerate (accept/retain), (ii) treat (control/reduce), (iii) transfer (insure/contract), or (iv) terminate (avoid/eliminate). However, for a consideration of risk capital, the distinction of two broad risk management strategies have a merit: risk control and risk finance. Risk control is directed toward the reduction of the probability and severity of risk and it is related to the application of prevention or repression techniques. Risk financing embraces tools that allow to obtain funding for a coverage of the financial consequences of risk, in particular, risk retention or risk transfer tools [42-44]. There is a relevant complementarity between risk control and risk financing strategies: The failure of risk control techniques increases the need for risk financing techniques. Thus, the investment in risk control techniques may significantly reduce the risk financing needs.

Risk capital is tightly connected with risk financing strategy and the need for risk capital is well explainable through the analysis of the consequences of risk occurrence from a corporate finance point of view. The implementation of risk management in a company is expected to increase its capabilities to create value. In this regard, the early empirical works examined the relationship between the implementation of insurance or derivatives and cash flow volatility [45-47]. In the contemporary approach (the ERM concept), the value-creation potential of risk management is also widely examined, often with reference to the measures of a company's efficiency (return on equity or assets most frequently) [37,48-51]. The general conclusion that could be drawn from the empirical findings is that the basic motive behind the implementation of risk management (and the related benefits) is the stabilization of expected cash flows. In other words, effective risk management implementation should be directed toward the elimination of unforeseen and undesired cash flow volatility, which reflects the ultimate consequences of risk occurrence.

These considerations are echoed in corporate finance theory, within the recognition of the problem of financial constraints and the related bankruptcy threat. As addressed by Mayers and Smith [45] and MacMinn [47], the ultimate risk consequences are manifested by the undesired cash flow volatility and may severely affect a company's financial position. In particular, the ability to maintain liquidity and financial balance is threatened, signaling the core symptoms of the financial distress. A financially distressed company has a difficulty in obtaining additional funding externally: A greater bankruptcy threat imposes higher bankruptcy costs (that are considered by capital providers) [52]. The concept of risk capital allows a better understanding of the necessity of the explicit consideration and preparedness of adequate risk financing tools (and the corresponding risk capital sources).

In this regard, risk capital $R C$ reflects the funds that a company may use to restore the undesired 'gap' in the real (obtained) cashflows $R(C F)$, as compared to the expected (planned) ones $E(C F)$, and to avoid the consequences of financial distress. Accordingly, for a given period of time $t$, if

$$
E(C F)_{t} \neq R(C F)_{t}
$$

risk capital allocation should result in

$$
E(C F)_{t}=R(C F)_{t}+R C_{t}
$$

The adoption of a risk capital concept (which is related to the choice of a risk financing strategy) may significantly influence the quality of the remaining elements of a risk management process. First of all, it improves the process of risk identification and assessment. The severity of risk should be assessed with reference to the impact of risk on the planned (future) cashflows, with reference to both direct and indirect consequences of a given risky event. A complex evaluation of risk should address the problem of risk velocity, which is defined as the interval between the occurrence of a risky event 
and its peak impact on the company [53], as reflected in cash flows volatility. The broadened and long-term analysis of the outcomes of a risky event is crucial for a well-designed implementation of risk management strategies (and tools within).

A second considerable contribution of the risk capital concept to the overall quality of the risk management process is related to the design of the ultimate shape of the applied risk management tools. This refers to the analysis of a company's risk resilience, which is determined by the availability of resources to manage risk-people, knowledge, equipment, as well as funds [53]. In other words, effective risk management depends on the current possession of resources, as well as the ability to obtain additional resources, if needed. In this regard, risk capital reflects the availability of funds (as resources) and the efficiency of risk management depends on the proper evaluation of the currently available funds, as well as the ability to obtain additional funding in terms of risk occurrence.

\subsection{Sustainable Dimension of Risk Capital}

The concept of risk capital also has relevant implications in the context of sustainability. The consideration of a sustainable dimension of risk capital derives from the relatively new conceptualization of sustainable corporate finance and sustainable risk management, as outlined below.

Soppe [54] laid the foundations for the contemporary understanding of the concept of sustainable corporate finance. With consideration of the premises of the theory of the firm (goals and metrics applied), human nature of economic actors, ownership paradigm and ethical framework, Soppe distinguished between the key elements of sustainable corporate finance (in comparison to the key elements of traditional and behavioral corporate finance approaches). In particular, Soppe concluded that the goals of sustainable corporate finance refer to a multi-attribute optimizer (that focuses on profit, people, and planet). Further, in the human actor dimensions, sustainable corporate finance requires a cooperative performance and trust. With reference to the ownership paradigm, sustainable corporate finance considers the portfolio of a company's stakeholders (consistent with stakeholders' theory $[55,56])$. Finally, an ethical framework of corporate finance should integrate the ethical virtues. In conclusion, Soppe [54] (p. 221) defined sustainable corporate finance as 'a financial policy that strives for triple-bottom-line performance measurement with human actors that opt for maximizing multi-dimensional preference functions'.

A formulation of the concept of sustainable corporate finance refers to the notion on the responsibility of the business community for incidents with major impacts on society and the natural environment [57]. In this regard, risk management is being considered as one of the 'sustainability mechanisms' that could be implemented on an organizational level [4]. The sustainable risk management (the SRM), however, may have various dimensions. In a narrow meaning, SRM requires a consideration (identification and assessment) of risks that result from sustainability challenges (e.g., technological development, scarcity of resources or climate change). In a broadened meaning, SRM requires the inclusion of the interdependencies between a company and the environment, as well as hidden vulnerabilities. In particular, it requires a consideration of the impact of a company's failures (as failures of its risk management) in environmental and socio-economic dimensions. For a broader discussion on various dimensions (and understanding) of sustainable risk management see Lessen et al. [4] and Spedding and Rose [15]. The relationship between corporate sustainability and risk management was also addressed in [58-60].

From the existing body of literature it could be concluded that corporate sustainability embraces both a sustainable approach in corporate finance decision-making and sustainable approach to risk management. In a narrower meaning, these issues are addressed on micro-level: an instrumental single company perspective, consistent with the classical theory of the firm [3,61]. Accordingly, sustainable corporate finance is directed toward a company's resilience in the long-run (and a synonym of bankruptcy avoidance). Then, sustainable risk management requires the decisions that allow a sustainable performance of a company. In this context, risk capital performs a vital buffering function: 
It ensures an injection of funds that may reduce the threat of bankruptcy in the aftermath of the cash flow volatility caused by a risky event (as a shock).

However, a micro-level consideration of sustainable corporate finance and sustainable risk management is substantial for a macro-level consideration: with reference to the situation of stakeholders and in the environmental and socio-economic context. A prevention of a single-company's bankruptcy is always relevant for its stakeholders (for instance the workers and their wealth, the society that needs the products or services supplied by a company, etc.). A well-designed and well-executed sustainable risk management ensures that a company will be able to respond quickly and effectively for any harm it has caused to the environment or the society. Stakeholders are the ultimate risk-bearers of a company's performance, and a sustainable company should distinguish itself with the courage to take only the calculated risks [54] (p. 220). The aforementioned considerations on the sustainable dimension of risk capital are framed in Figure 2.

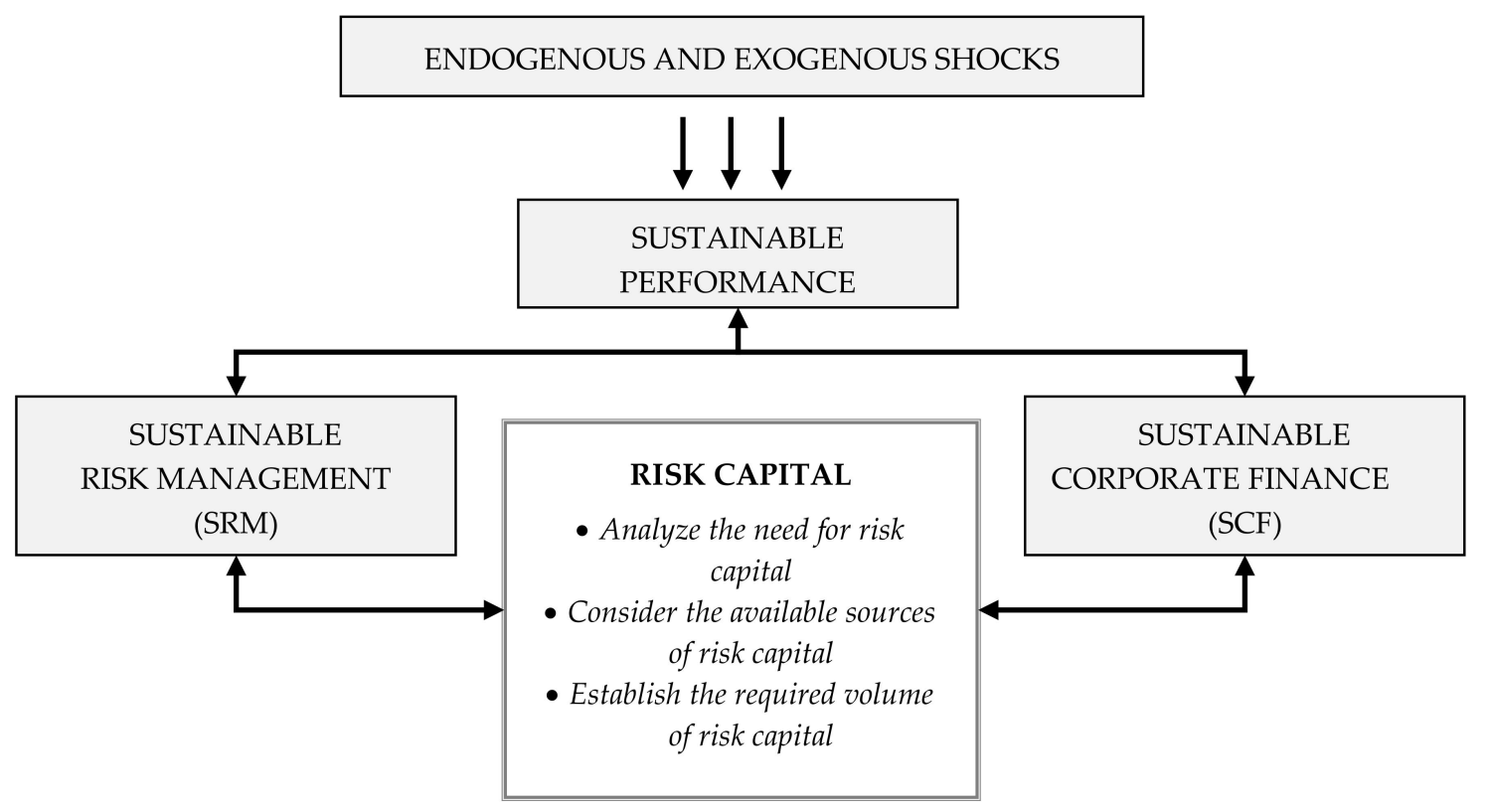

Figure 2. Sustainable dimension of risk capital Source: Own study.

To provide a practical insight to the relevance of risk capital in sustainable dimension, it is worth recalling the examples of disastrous events that attracted public awareness both due to the scale of their consequences, as well as the long-term ecological and socio-economic impact. It is believed in the risk management discipline that lessons are better learned from a study of the causes of previous disastrous events. In this respect, to highlight the failures in risk analysis and inadequate risk preparedness, we refer briefly to the Deep Water Horizon oil spill and Fukushima nuclear disaster. Both events are regarded as examples of cascading disasters [62], which is a synonym of an extreme disaster leading to further extreme consequences that emerge over time. In addition, both events refer to the importance of a proper risk response strategies and a readiness to react immediately to stop the negative impact of risk.

The Deep Water Horizon oil spill is an example of a man-made disaster. This industrial disaster began on 20 April 2010 in the Gulf of Mexico on the BP-operated Macondo Prospect. The disaster is considered as the largest marine oil spill in the history of the petroleum industry and caused a tremendous damage to wildlife, tourism, and fisheries and imposed high cleanup costs [63]. British Petroleum was responsible for ensuring that the well in the Gulf of Mexico was operated safely and in an environmentally responsible manner. Thus, on a single-company dimension, the consequences of the Deep Water Horizon oil spill are measured, primarily, with the increased expenditures (as on January 2016 BP announced USD 1.7 billion charges for expenses related to the disaster [64]), and the 
related decrease in value. However, BP also stands as an example of ecological and reputational damage [65]. A detailed analysis of the causes of the disaster (In a technical context, the causes and consequences of Deep Water Horizon disaster were examined for instance in $[66,67]$ ) allowed to blame BP's executives for improper risk management. In this respect, three key areas were questioned: (a) untimely plan changes; (b) failure to identify and respond to the indicators of the critical problems, and (c) inadequate response to the environmental harm in the aftermath of the sinking of the rig [65]. The Deep Water Horizon disaster is, thus, an example of a failure of a risk management system - the pressure of time and cost savings overrode the safety concerns.

The Fukushima nuclear disaster is an example of a coincidence of the impact of natural forces and human failures. The energy accident in the Fukushima Daiichi Nuclear Power Plant, located in Okuma, Japan, was initiated by the extreme Tohoku earthquake on 11 March 2011, followed by tsunami waves of 13 to $15 \mathrm{~m}$ high that overtopped the plant's 5 to $7 \mathrm{~m}$ seawall. As a consequence, water disabled the emergency generators to cool the reactors. Due to insufficient cooling, three nuclear explosions lead to a release of radioactive material $[68,69]$. The contamination affected the coastal area, as well as the Pacific Ocean. In the risk management failure context, Fukushima disaster is an example of inadequate risk anticipation and risk assessment during the design of the plant, which was combined with inadequate response capabilities. Although the nuclear accident was caused by the unprecented earthquake and tsunami, human mistakes were responsible for numerous inadequate safety countermeasures, as well as for the cumulation of technical lapses [70,71].

The examples of Deep Water Horizon oil spill and Fukushima nuclear disaster indicate the possible severity of the negative risk outcomes. On the single-company's level, the ultimate severity of risk is countable (increased costs, lost revenues, destroyed value), but often remains uncountable on an environmental and social level. Business failures are somehow inevitable-it seems impossible to identify all risks and perfectly assess the impact of these risks. However, a company shall always try to avoid the mistakes and be prepared to respond to the negative risk outcomes. In this regard, the concept of risk capital is particularly useful. It helps to evaluate the financial preparedness for the consequences of risk occurrence and to assess a company's ability to sustain. Accordingly, in the conceptual dimension, risk capital enables a company to respond immediately to the consequences of risk, in particular-to provide funds to stop the harm caused on an environmental and/or socio-economic level.

\section{Applicative Dimension: Sources of Risk Capital}

\subsection{General Considerations}

Operationalization of the concept of risk capital requires the identification of its sources. The sources of risk capital should be defined as the financing mechanisms that channel the funds to a coverage of the negative financially measurable risk outcomes. As it was assumed, on a company's level, the negative risk outcomes are manifested by the unforeseen and undesired cash flow volatility and risk capital is the injection of funds that help a company to sustain (see Equations (9) and (10)). In this respect, the sources of risk capital embrace various instruments and solutions that allow a company to obtain funds to restore its financial position in the aftermath of a risky event.

The distinction of the particular sources of risk capital, however, requires a short notion on the important features of these sources. The authors' proposal of the taxonomy of risk capital sources is framed in Table 1. The classification is non-exclusive. 
Table 1. The non-exclusive classification of the sources of risk capital for corporate end-users.

\begin{tabular}{|c|c|c|}
\hline Feature & $\begin{array}{l}\text { Types of the Sources } \\
\text { of Risk Capital }\end{array}$ & Characteristics \\
\hline \multirow{2}{*}{ Balance sheet consideration } & $\begin{array}{l}\text { Balance-sheet captured } \\
\qquad\left(R C_{E} \text { and } R C_{D}\right)\end{array}$ & Traditional debt and equity sources \\
\hline & Off-balance sheet $\left(R C_{C T}\right)$ & $\begin{array}{l}\text { Contingency funding (option on capital; the } \\
\text { pay-off of the option dependent on the } \\
\text { occurrence of a risky event) }\end{array}$ \\
\hline \multirow{3}{*}{ Moment of capital allocation } & Pre-loss funding & Funds injected before the risk occurrence \\
\hline & Post-loss funding & $\begin{array}{l}\text { Funds injected in the aftermath of } \\
\text { risk occurrence }\end{array}$ \\
\hline & Ongoing loss funding & $\begin{array}{l}\text { Loss continuously incurred in profit and } \\
\text { loss account (as operating cost) }\end{array}$ \\
\hline \multirow{2}{*}{$\begin{array}{l}\text { Ultimate bearers of the financial } \\
\text { risk outcomes }\end{array}$} & Pure retention & $\begin{array}{l}\text { Risk ultimately born by company's } \\
\text { stockholders (owners) }\end{array}$ \\
\hline & Pure transfer & $\begin{array}{l}\text { Risk ultimately born by company's } \\
\text { stakeholders (third parties) }\end{array}$ \\
\hline \multirow{3}{*}{$\begin{array}{l}\text { Innovativeness of risk financing } \\
\text { mechanism }\end{array}$} & $\begin{array}{l}\text { Combination of retention } \\
\text { and transfer }\end{array}$ & $\begin{array}{l}\text { Risk dispersed between stockholders } \\
\text { (owners) and shareholders (third parties) }\end{array}$ \\
\hline & Traditional & $\begin{array}{l}\text { Risk financing mechanisms traditionally } \\
\text { implemented in companies }\end{array}$ \\
\hline & Alternative & $\begin{array}{l}\text { Risk financing mechanisms adapted from } \\
\text { insurance/reinsurance sector and } \\
\text { capital markets }\end{array}$ \\
\hline
\end{tabular}

Source: Own study.

The first set of features refers to the balance sheet perspective (respectively to the model outlined in Section 2.1). Some sources of risk capital are captured in the balance sheet-if the capital is obtained as a debt (e.g., bank loan) or equity (e.g., the issue of new shares or the increase of retained earnings). However, some sources are not directly captured in the balance sheet on their implementation (but often are visible on their usage). These sources reflect contingency funding, as the injection of funds is contingent on the risk occurrence. Contingency funding performs as option-like contracts: A company purchases the option for additional stream of funds, and the execution of the option is related to the occurrence of a predefined risky event [11]. The examples of this type of funding are all risk transfer mechanisms (in this insurance and derivatives).

The second set of the proposed risk capital features refers to the moment of risk capital allocation. In this regard, the proposed taxonomy distinguishes between pre-loss, post-loss and ongoing loss funding. The pre-loss funding refers to these sources of risk capital that are injected into the company before the occurrence of the risk. An example is all types of earmarked capital reserves, as well as the bank credit lines. Accordingly, the post-loss funding is injected after the risk occurrence (e.g., a bank loan to restore assets damaged by the risky event). A third possible solution is an ongoing loss financing which refers to the intentional inclusion of a loss in the profit and loss account, as the operating costs. However, ongoing loss financing is rational only for the relatively small, but frequent losses. In accordance with the concept of risk capital, the pre-loss, post-loss or ongoing loss funding should be explicitly embedded in risk financing strategies.

The third set of the proposed features of risk capital sources (as addressed in Table 1) is the consideration of the ultimate bearers of the consequences of risk. In this regard, the distinction between pure risk retention or pure risk transfer is essential. A pure risk retention means that a company (and its shareholders) are the ultimate bearers of the financial outcomes of risk, as these outcomes are financed by the company itself. On the contrary, a pure risk transfer means that a company is able to shift the financial outcomes of risk on a third party (a defined stakeholder). However, Table 1 provides a third possible solution - the intentional combination of retention and transfer in desired proportions. The combination should be preceded by the assessment of the scale of a company's ability to self-sustain (retain) the risk outcomes.

The fourth set of features of the sources of risk capital considers the innovativeness of the risk financing mechanism. Traditional sources of risk capital embrace all sources that are well established 
in the practice of corporate risk management. In other words, these sources of risk capital refer to the risk financing tools that are easily obtainable for companies. Insurance market or debt and equity finance stand here as the examples. The innovative sources of risk capital embrace the state-of-the-art solutions from the corporate end-users' point of view. These solutions are often well established in the practice of insurance and reinsurance sector or on financial markets but are relatively rare in corporate risk management (and in this context are regarded as innovative). These sources embrace a group of so-called Alternative Risk Transfer (the ARTs) solutions that are distinguished by a tailor-made and multi-year approach in their design [72-74]. The distinction between traditional and alternative sources of risk capital is subject to the presentation of the universe of risk capital sources available for corporate end-users, outlined in the remainder of Section 3.

\subsection{Traditional Sources of Risk Capital}

In the traditional concept of risk management (as aforementioned in Section 2), the primary decision is whether to transfer the risk or not. Not surprisingly, the implementation of risk transfer mechanisms has a straightforward connotation to the risk management process (and is even treated as its synonym). Accordingly, among the typical traditional sources of risk capital, we shall place (i) the insurance risk transfer, (ii) and the transfer of risk with the application of derivatives, and (iii) risk retention.

Insurance belongs to the oldest tools of risk management (as it was used in ancient times by the Phoenicians and in ancient China [75]). In the insurance contract, a company defines the type (or types) of risky events that are insured, as well as determines the value of the subject of the insurance contract (company's assets or liabilities) - the insurance sum. In the case of the occurrence of the predefined risky event, a company receives an injection of funds (in the form of insurance remuneration). The stream of funds depends, obviously, on the scale of the damage and could not exceed the previously established insurance sum (as a defined level of the possible financial commitment of the insurance company). The corporate insurance markets (and insurance products) allow to insure various types of tangible and intangible assets, as well as the possible future liabilities (e.g., due to legal liability of a company). Recently we observed a growing interest in the insurance of the loss of profit due to the damage of assets and the related break in the operating performance (known as the business interruption insurance) [18,44,76].

Derivatives (in particular the forward contracts) are also considered as one of the oldest risk management techniques (dated back to antiquity [77]). The derivatives are defined as 'bilateral contracts whose value is derived from the value of some underlying assets, reference rate or index' [33] (p. 264). A company may use derivatives in the hedging function to protect against the unfavorable changes of the value of its assets, liabilities or expected cash flows. In particular, if there is a decrease in the value of the assets, a derivative contract provides a stream of funds that counterbalances the loss. In companies, the derivatives are primarily executed to hedge against the financial consequences of the foreign exchange risk (for assets, liabilities, and cash flows denominated in a foreign currency) or the interest rate risk. Depending on the rights admitted to both sides of the contract, as well as the approach to the execution of the contract, we may distinguish between forward, futures, options or swaps, or their combinations $[78,79]$.

In a traditional risk management approach, the advantages of risk transfer are often balanced against the disadvantages of risk retention. The implementation of risk retention is justified only if it is a conscious, intentional, and planned company decision, preceded by a well-executed analysis of the scale of risk outcomes. It is often addressed that a certain level of risk retention is inevitable in a company. The improperly recognized risk (both in the type of the event, as well as its frequency and severity) ultimately leads to its retention. Thus, risk retention could be perceived as the residual (default) risk management technique [42,43]. Within the implementation of risk retention, risk capital could be sourced from (a) earmarked capital reserves, (b) bank credit-lines, and (c) compensation. Earmarked capital reserves are related to the intentional accumulation of funds, that are assigned 
for coverage of a predefined risk. Typically, the funds are held as a stock of liquid or semi-liquid assets. 'Self-insurance' is perceived as a particular example of earmarked capital reserves if (a) retention is decided for a risk that could be subject to insurance, (b) a company implements adequate risk-measurement techniques (similar to those executed in the insurance business) to estimate the possible risk outcomes, and (c) the earmarked capital reserves are safeguarded against the 'cookie jar' effect (the use of the funds for purposes other than initially planned). [72,73]. To some extent, from the balance sheet perspective, earmarked capital reserves could be substituted by the pre-agreed bank credit lines. Credit lines offer a company a chance to obtain an injection of debt financing, whenever needed, up to a defined credit limit. Compensation is the constant inclusion of the losses in the profit and loss account, as operating costs. Compensation is justified for high-frequency, low-severity losses, that could be adequately estimated. Compensation is applicable to companies that are able to generate operating revenues in excess of operating costs [76].

The aforementioned features of traditional sources of risk capital are summarized in Table 2.

Table 2. The features of traditional sources of risk capital.

\begin{tabular}{cccc}
\hline \multirow{2}{*}{ Source } & \multicolumn{3}{c}{ Feature } \\
\cline { 2 - 4 } & Balance Sheet Consideration & Moment of Capital Injection & Ultimate Risk Bearers \\
\hline Insurance & Off-balance sheet & Post-loss funding & Transfer \\
Derivatives & Off-balance sheet & Post-loss funding & Transfer \\
Earmarked capital & Balance sheet captured & Pre-loss funding & Retention \\
reserves & Off-balance sheet & Post-loss funding & Retention \\
Credit lines & Balance sheet captured & Ongoing loss funding & Retention \\
Compensation & (through the net profit) & &
\end{tabular}

\subsection{Alternative Sources of Risk Capital Available for Corporate End-Users-Brief Overview}

Alternative sources of risk capital embrace various solutions that are less common in the practice of corporate end-users, but may potentially gain a greater consideration in the future. In this regard, we refer here briefly to the possible implementation of (i) captives, (ii) finite risk programs, (iii) multi-risk products, and (iv) Insurance Linked Securities. The presentation of the alternative sources of risk capital is focused on the explanation of the core premises of the funding mechanism upon, as well as on the notion on the applicability of these sources in non-financial companies.

Captives were initiated in the 1960s, and then grew in popularity in the 1970s in response to the hardening of the insurance markets. Captive is defined as an insurance company that is wholly owned by the sponsor-the parent company (or a group of related companies). In other words, the sponsor establishes its own insurance company, and in this context, captive could be perceived as a synonym of self-insurance [80,81]. However, the establishment of a captive offers numerous benefits in comparison to the purchase of traditional insurance. Typically, the benefits of captives are associated with the tax incentives (as captives are mostly located in tax heavens). However, from a risk management perspective, captives allow access to the reinsurance market which offers some elasticity in the protection against risks that are uninsurable on the traditional insurance market. Moreover, a sponsor has an impact on the cost of insurance premium and the process of the payment of the remuneration in the case of a loss. In this regard, captive could be considered as a source of risk capital, as it is related to the injection of funds in the case of risk occurrence-the funds that are obtained through a sophisticated mechanism that combines retention and insurance risk transfer (The types of captives and a detailed analysis of the related benefits and costs is provided in [81-83]).

Finite risk programs belong to the solutions that are typical for the reinsurance market. However, these programs have been successfully implemented by corporate end-users in recent decades [84]. Finite risk programs are tailor-made agreements that combine risk retention and risk transfer. There are two basic 'models' of the agreement: the prospective loss contract and the retrospective loss contract. 
The prospective loss contract is similar to the formation of an earmarked capital reserve-a company gathers sources on a so-called 'experience' account and pays the commitment fee to the partner in the contract. In the case of the risk occurrence, the partner is ready to cover the risk outcomes that are in excess of the funds collected on the experience account. However, the financial commitment of the partner in the contract is limited (finite). The retrospective loss contract is similar to debt financing, as the contract assumes the payment of continuous instalments by the company, in exchange for the initial injection of funds received shortly in the aftermath of the risk occurrence (The aforementioned frameworks of finite risk contracts are executed in various types of agreements obtainable on the reinsurance market-e.g., the LPT (Loss Portfolio Transfer), ADC (Adverse Development Cover), spread loss, finite quota share contracts $[72,85])$. The finite risk programs are a relatively interesting source of risk capital for the companies that wish to protect against the risk that is difficult to insure (e.g., emerging risks). However, it is difficult to estimate the scale of the implementation of the finite risk programs by corporate end-users, due to the limited transparency to protect the know-how rights. As reported by Culp and Heaton [84] (pp. 25-26), the released information on the implementation of finite risk contracts by corporate-end users were the examples of large companies which protected themselves against the risks regarded as uninsurable (asbestos loss and risks related to the merger and acquisition procedure.

There are also examples of alternative risk transfer mechanisms that represent an innovative approach to the implementation of insurance risk transfer-the multi-risk products. The first example is the MMPs (Multi-line, Multi-year Products). MMPs perform as long-term insurance contracts that integrate various types of insurable risk (insurance lines) with the settlement of a retention limit (insurance company covers the losses in excess of a defined retention limit) $[83,86]$. The second example is MTPs (Multi-trigger Products). Under the MTPs contracts, the injection of funds is directed to the company if there is a coincidence of a predefined two (or more) risky events. Typically, one event is an insurable risk, whereas the second one is uninsurable (e.g., the changes in the demand on the market). The idea behind the implementation of the MTPs is that a company could easily sustain the occurrence of the insurable event or the uninsurable one, but the coincidence (simultaneous occurrence) of both may severely threaten its performance [11,86]. The MMPs and MTPs are more common in the corporate end-users and are usually implemented in larger companies (Some examples were presented in [11], pp. 593-597; [87]).

Insurance-Linked Securities (the ILSs) are regarded as the products of the ongoing convergence of capital and insurance market, that was initiated in the early 1990s. ILSs represent a group of various financial instruments (bonds, notes, derivatives), with the pay-off structure tied to defined indices [88,89]. These indices could be related to the occurrence of catastrophic events (e.g., hurricanes or earthquakes), as well as weather-related events (e.g., temperature, rainfall or windspeed indices). The market of ILSs is evolving as these instruments allow the effective investment portfolio diversification (as the insurance risks are not correlated to capital market risks). Among various forms of the ILSs, non-financial companies may potentially source risk capital with:

- Insurance derivatives - the pay-off depends on the changes of a predefined risk index (that reflects the occurrence of risk); companies may implement the catastrophic derivatives (indices related to the cumulation of losses in the aftermath of a catastrophic event) or weather derivatives (indices capture extreme weather conditions);

- Catastrophic bonds-the coupon payment of the catastrophic bonds is determined by the changes of a defined catastrophic risk index; the issuer (a company) is allowed to reduce or release the payment of the coupon in the aftermath of the catastrophic risk (a detailed mechanism of the issuance of catastrophic bonds is presented in $[83,89]$ ) (The information on the issuance of corporate bonds by non-financial companies is obtainable in the ARTEMIS database [90]);

- Contingent capital structures [11,83]—contractual agreements that allow a company to issue bonds or shares, if a predefined risk occurs; the partner of the contract (usually a bank) is responsible for the sale of the bonds or shares to the institutional investors. 
The aforementioned features of the alternative sources of risk capital are summarized in Table 3.

Table 3. The features of alternative sources of risk capital.

\begin{tabular}{|c|c|c|c|}
\hline \multirow{2}{*}{ Source } & \multicolumn{3}{|c|}{ Feature } \\
\hline & Balance Sheet Consideration & Moment of Capital Injection & Ultimate Risk Bearers \\
\hline Captives & $\begin{array}{l}\text { Partially balance sheet captured } \\
\text { (the equity contribution of the } \\
\text { parent company) }\end{array}$ & Post-loss funding & Combined \\
\hline Finite risk programs & Off-balance sheet & $\begin{array}{l}\text { Pre-loss funding or post-loss } \\
\text { funding } \\
\text { (depending on the type of the } \\
\text { program shape) }\end{array}$ & Combined \\
\hline $\begin{array}{l}\text { Multi-risk products } \\
\text { (MMPs and MTPs) }\end{array}$ & $\begin{array}{l}\text { Off-balance sheet in transfer } \\
\text { part, balance sheet captured in } \\
\text { retention level }\end{array}$ & Post-loss funding & Combined \\
\hline Insurance derivatives & Off-balance sheet & Post-loss funding & Transfer \\
\hline Catastrophic bonds & Off-balance sheet & Post-loss funding & Transfer \\
\hline $\begin{array}{l}\text { Contingent capital } \\
\text { structures }\end{array}$ & Off-balance sheet & Post-loss funding & Retention \\
\hline
\end{tabular}

Source: Own study.

As can be observed, in comparison with the features of traditional risk capital sources framed in Table 2, the universe of the alternative risk capital sources is more complex. Most of these sources are off-balance sheet ones, and some are examples of the intentional combination of risk transfer with risk retention.

\section{Conclusions and Final Remarks}

The main purpose of this study was to explain the concept of risk capital and advocated for its implementation in non-financial companies. On a conceptual level, the motives behind risk capital implementation were considered, from a sustainable risk management and sustainable corporate finance point of view. As this problem has not been widely addressed in the literature, this study may enhance further development of a comprehensive and unequivocal framework and empirical investigations within.

The study has demonstrated that the universe of the sources of risk capital available for corporate end-users is relatively wide. The traditional sources of risk capital, however, seem more accessible for the smaller companies (SMEs sector) and operating on the markets of less-developed risk management practices. Obviously, with a shift from a traditional approach to risk management (single-risks oriented, focused on the effective implementation of risk transfer mechanisms) to the ERM approach (holistic and integrated with all areas of decision-making), the 'universe' of accessible solutions enlarged and the alternative, state-of-the-art sources of risk capital, became obtainable. However, the practical implementation of the risk capital concept in risk management (in its sustainable dimension) faces some relevant obstacles and limitations that may lead to important 'tensions' worth considering here. In this context, the possible directions and limitations of further empirical investigations were addressed below as well.

First of all, the inclusion of the risk capital concept has an impact on the understanding of the components of a company's capital structure and the related cost of capital estimation. Traditionally, capital structure theories refer to the optimal combination of debt and equity. Accordingly, the cost of capital account weights the cost of debt and equity with the scale of its implementation in a company (as reflected by the WACC (weighted average cost of capital computations)). The balance sheet risk capital is explicitly included in this account. However, the recognition of the off-balance sheet risk capital raises a question on the rationale behind the modification of the cost of capital formula, as specified in Table A1 (Appendix A). The problem was addressed by Shimpi [12] who postulated the use of TACC (total cost of capital) concept (see Appendix A). With an example of the insurance contract, Shimpi advocated for the inclusion of the cost of risk capital (expressed as the insurance premium relative to 
the value of insurance contract) and, respectively, the inclusion of the value of insurance contract as an additional source of capital. The main drawback of this concept is the significant reduction of the weighted average cost of capital if the insurance is included in computations. Thus, further discussion on the shape of proposals of the cost of capital modifications by Doherty [13] and O'Brien [14] was related to the consideration of the price of risk capital. Although the problem of the modification of the cost of capital account (as a result of the implementation of risk capital or risk management in general) is scarcely addressed in the literature, it seems that it has some merit in the decision-making context. For a company's internal decisions on the implementation (or the combination) of risk capital sources, the modified approach to cost of capital computation (and in particular, the inclusion of the cost of risk capital sources) may enhance more efficient decisions within.

The second relevant limitation, which is partially related to the modification of the cost of the capital account, is the measurement of the cost of particular sources of risk capital. There again, the problem is particularly relevant for the sources of risk capital that are not captured in the balance sheet (the contingent ones). However, the sources of risk capital are contract-based solutions, with defined commitment fees or premiums to be paid in advance. Thus, it seems reasonable to compute the cost of a given source of risk capital as the sum of the imposed costs relative to the volume of the potentially obtainable injection of funds, determined as the value of the contract. In some cases, however, this approach may face some limitations (e.g., in the case of captives).

The third relevant limitation is related to the quest on the efficiency of the implementation of some of the risk capital sources, with respect to considerations of the existing corporate finance theory. As a good example stands the retention of risk in the form of earmarked capital reserves. In a company, the existence of earmarked capital reserves is reflected in the holding of liquid or semi-liquid assets and is associated with a company's financial slack, as it represents the available resources. In the literature, however, financial slack was examined as a good, as well as a bad phenomenon. The good side of financial slack is related to its buffering function (directly referring to the risk capital concept) - the slack as a resource concept, which considers slack as a cushion against the disruption caused by endogenous and/or exogenous forces [91,92]. In this respect, slack as a resource enhances a company's performance, as a company is better equipped to respond to the changes imposed by its environment. However, there is also a concept of slack as inefficiency-a holding of slack negatively impacts a company's performance, as it may enhance the waste of idle resources for empire-building purposes (agency theory considerations), potentially imposes significant opportunity costs of liquidity (cash is an unproductive asset) or enhances a wrong understanding of the buffering function of slack (as slack performs as a safety net for wrong decision making) [93-96]. The example of the implementation of a relatively simple source of risk retention may raise numerous doubts, in this the question of the rationale behind its implementation in comparison to other obtainable sources of risk capital. Possibly, greater sophistication of the given source of risk capital (e.g., in the case of alternative ones) may, in turn, lead to greater doubts and tensions. The aforementioned considerations have two relevant implications for the implementation of various sources of risk capital: (1) The decisions should be preceded by a careful cost-benefit analysis, and (2) the decision should be adequately disclosed, to ensure transparency of actions and understanding of the rationale behind these actions.

The fourth relevant limitation is related to the sustainable dimension of the concept of risk capital. A careful reader may ask a question: Why risk capital is discussed in this paper as a 'concept', whereas it seems that risk capital is a synonym of risk financing (as one of risk management strategies)? The origins of risk capital as a concept refer straightforwardly to its sustainable dimension: Risk capital reflects the funds that are explicitly made available to help to 'heal' a company in the case of risk. Thus, both in financial and non-financial companies, the concept of risk capital corresponds with the availability of funds that could be allocated to cover the losses. Such an approach highlights the relevance of the a priori preparedness and requires a more conscious consideration of risk and its consequences (in this the whole spectrum of environmental and socio-economic impacts in the short and long run). The consideration of the variety of the available sources of risk capital 
enhances more conscious and more efficient decisions within the implementation of a company's risk financing strategy.

The aforementioned tensions and limitations within the decision-making context of risk capital concept applicability are also relevant for the empirical investigations within. A first compelling research issue is whether the companies intentionally define and follow any strategies on how to obtain and compose risk capital sources. However, a hidden (off-balance sheet) nature of most of the sources of risk capital limits the availability of reliable data. In addition, in the case of the balance-sheet sources of risk capital, the examination of strategies remains limited. For instance, retention seems one of the simplest and most accessible sources of risk capital. The information on planned retention is reflected in the company's holdings of liquid assets. However, a company may hold a stock of liquid assets for other purposes than risk retention. Thus, empirical investigations should be, first, directed toward the verification of the motives behind the holding of liquid assets (precautionary motive or other). Another interesting field of empirical investigation is a company's strategies within the implementation of alternative risk capital sources. As it was addressed in Section 3.3, the application of a more sophisticated solution was reported in several case studies. However, the protection of the know-how rights is as a prime barrier in the release of the details of these transactions. Probably, the use of ILSs and captives remain the best recognized, as the information is obtainable in dedicated databases. In addition, the inquiries could be placed within the overall barriers of the implementation of alternative risk capital sources, such as the level of familiarity of these solution to risk managers (as decision makers), as well as the existing legal barriers (e.g., tax system considerations).

An interesting field of the possible empirical investigation is the context of corporate finance decision making. Numerous studies have examined the benefits of the implementation of insurance or derivatives, as proxied by profitability, efficiency or value creation measures. However, the investigation whether companies examine and evaluate their needs for risk capital and execute any financially-measured comparisons within is still a challenge. There again, any reliable comparisons are limited by the hidden nature of risk capital sources and limited scale of its disclosure. Thus, it seems that case-studies research or well-designed questionnaires are the first-choice methods of empirical investigations. The cross-companies comparative studies, however, seem feasible within a piecemeal dimension (single risk capital source oriented).

Funding: The research was funded by the National Science Center, Poland, Decision No DEC-2011/01/ D/HS4/04003, within the problems raised in Section 2.1 (the origins of risk capital) and in Section 3 (sources of risk capital).

Conflicts of Interest: The authors declare no conflict of interest.

\section{Appendix A}

Table A1. The possible approaches to the modified computation of the cost of capital in terms of risk capital implementation.

\begin{tabular}{|c|c|}
\hline Concept & Cost of Capital Computations \\
\hline $\begin{array}{c}\text { Traditional approach } \\
\text { (derived from Modigliani-Miller } \\
\text { substitution theory) }[97,98]\end{array}$ & $\begin{array}{c}\text { WACC }=C_{E} \times \frac{E}{(E+D)}+C_{D} \times \frac{D}{(E+D)} \\
\text { where: WACC—weighted average cost of capital, E-equity, D-debt, } C_{E} \text {-cost of equity, } \\
C_{D} \text {-after-tax cost of debt }\end{array}$ \\
\hline $\begin{array}{c}\text { TACC } \\
\text { (P. Shimpi 2002; [12]) }\end{array}$ & $\begin{array}{c}T A C C=C_{E} \times \frac{E}{(E+D+R C)}+C_{D} \times \frac{D}{(E+D+R C)}+C_{R C} \times \frac{R C}{(E+D+R C)} \\
\text { where: TACC-total average cost of capital, } E \text { - equity, } D \text {-debt, } R C \text { - risk capital, } C_{E} \text {-cost of } \\
\text { equity, } C_{D} \text {-after-tax cost of debt, } C_{R C} \text { - cost of risk capital }\end{array}$ \\
\hline $\begin{array}{c}\text { WACC } \\
\text { (N.A. Doherty 2005; [13]) }\end{array}$ & $\begin{array}{c}\qquad W A C C=C_{E} \times \frac{E}{(O C+R C)}+C_{D} \times \frac{D}{(O C+R C)} \\
\text { and } O C+R C=D+E \\
\text { where: WACC—weighted average cost of capital, } E \text { - equity, } D \text {-debt, OC—operating } \\
\text { capital, } R C \text {-risk capital, } C_{E}-\text { cost of equity, } C_{D} \text {-after-tax cost of debt }\end{array}$ \\
\hline $\begin{array}{c}W_{A C C_{R M}} \\
\left(\mathrm{O}^{\prime} \text { Brien 2006; [14]) }\right.\end{array}$ & $\begin{array}{c}\qquad W_{A C C_{R M}}=C_{O C} \times \frac{O C}{(O C+R C)}+R_{R F} \times \frac{R C}{(O C+R C)} \\
\text { where: } W A C C_{R M} \text {-weighted average cost of capital in terms of risk management, } O C \text {-operating } \\
\text { capital, } R C \text {-risk capital, } C_{O C} \text { cost of operating capital, } R_{R F} \text {-risk free rate (as the equivalent of } \\
\text { the cost of risk capital) }\end{array}$ \\
\hline
\end{tabular}




\section{References}

1. Norman, W.; Mac Donald, C. Getting to the bottom line. Bus. Ethics Q. 2004, 14, 234-262. [CrossRef]

2. Baker, H.K.; Nofsinger, J.R. Socially Responsible Finance and Investing: Financial Institutions, Corporations, Investors and Actions; Wiley: Hoboken, NJ, USA, 2012.

3. Salzmann, A.J. The integration of sustainability into the theory and practice of finance: an overview of state of the art and the outline of future developments. J. Bus. Econ. 2013, 83, 555-576. [CrossRef]

4. Lessen, J.; Dentchev, N.A.; Roger, L. Sustainability, risk management and governance: Towards an integrative approach. Corp. Gov. 2014, 14, 670-684. [CrossRef]

5. Spedding, L.; Rose, A. Business Risk Management Handbook. A Sustainable Approach; CIMA Publishing/ Elseviere: Burlington, UK, 2008; pp. 17-28.

6. Basel Committee on Banking Supervision. Basel III: A global regulatory framework for more resilient banks and banking systems. Bank for International Settlements, Basel, Switzerland. Available online: https:/ / www.bis.org/publ/bcbs189.pdf (accessed on 15 December 2018).

7. Bar, A.; Liao, C.; Strassner, M. What Do You Know About Solvency II? High-Level Introduction for Interested Parties from Non-EU regions; Swiss Reinsurance Company: Zurich, Switzerland, 2013.

8. Liebwein, P. Risk Models for Capital Adequacy: Applications in the Context of Solvency II and Beyond. Geneva Pap. Risk Insur. Issues Pract. 2006, 31, 528-550. [CrossRef]

9. Elderfield, M. Solvency II: Setting the Pace for Regulatory Change. Geneva Pap. Risk Insur. Issues Pract. 2009, 34, 35-41. [CrossRef]

10. Eling, M.; Schmeiser, H.; Schmit, J.T. The Solvency II Process: Overview and Critical Analysis. Risk Manag. Insur. Rev. 2007, 10, 69-85. [CrossRef]

11. Culp, C. Structured Finance and Insurance. The ART of Managing Capital and Risk; John Wiley \& Sons: Hoboken, NJ, USA, 2006.

12. Shimpi, P. Integrating Risk Management and Capital Management. J. Appl. Corp. Finan. 2002, 14, $27-40$. [CrossRef]

13. Doherty, N.A. Risk Management, Risk Capital, and the Cost of Capital. J. Appl. Corp. Finan. 2005, 17, $119-123$. [CrossRef]

14. O'Brien, T.J. Risk Management and the Cost of Capital for Operating Assets. J. Appl. Corp. Finan. 2006, 18, 105-109. [CrossRef]

15. Dickinson, G. Enterprise Risk Management: Its Origins and Conceptual Foundation. Geneva Pap. Risk Insur. 2001, 26, 360-366. [CrossRef]

16. Hoyt, R.E.; Liebenberg, A.P. The value of enterprise risk management. J. Risk Insur. 2011, 78, 795-822. [CrossRef]

17. Zhou, C. Are Banks Too Big to Fail? Measuring Systemic Importance of Financial Institutions. Int. J. Cent. Bank. 2010, 6, 205-250. [CrossRef]

18. Diacon, S.R.; Carter, R.L. Success in Insurance, 3rd ed.; John Murray: London, UK, 1992.

19. Dowd, K. The case for financial Laissez-Faire. Econ. J. 1996, 106, 679-687. [CrossRef]

20. Sorkin, A.R. Too Big to Fail. The Inside Story of How Wall Street and Washington Fought to Save the Financial System—and Themselves; Penguin Books: New York, NY, USA, 2018.

21. Acharya, V.; Philippon, T.; Richardson, M.; Roubini, N. The Financial Crisis of 2007-2009: Causes and Remedies. In Restoring Financial Stability. How to Repair a Failed System; Acharya, V., Richardson, M., Eds.; John Wiley \& Sons: Hoboken, NJ, USA, 2009; pp. 1-56.

22. Merton, R.C.; Perold, A.F. Theory of Risk Capital in Financial Firms. J. Appl. Corp. Finan. 1993, 6, 16-32. [CrossRef]

23. Saunders, A.; Allen, L. Credit Risk Measurement. New Approaches to Value and Risk and Other Paradigms; John Wiley \& Sons: New York, NY, USA, 2002.

24. Klaassen, P.; Van Eeghen, I. Economic Capital; Elsevier: Burlington, NJ, USA, 2010.

25. Bessis, J. Risk Management in Banking, 3rd ed.; John Wiley \& Sons: Chichester, NH, USA, 2010.

26. RiskMetricsTM-Technical Document. Morgan Guaranty Trust Company of New York. 1996. Available online: http:/ / pascal.iseg.utl.pt/ \{\}aafonso/eif/rm/TD4ePt_2.pdf (accessed on 15 December 2018).

27. Lam, J. Enterprise Risk Management. From Incentives to Controls; John Wiley \& Sons: Hoboken, NJ, USA, 2003. 
28. Belmont, D.P. Value Added Risk Management in Financial Institutions. Leveraging Basel II and Risk Adjusted Performance Measurement; John Wiley \& Sons: Singapore, 2004.

29. Shimpi, P. Integrating Risk Management. In Financial Intermediation in the 21st Century; Mikdashi, Z., Ed.; Palgrave McMillan: London, UK, 2001; pp. 33-57.

30. Shimpi, P. Leverage and the Cost of Capital in the Insurative Model. 2004. Available online: http:/ / www. actuaries.org/AFIR/Colloquia/Boston/Shimpi.pdf (accessed on 15 June 2017).

31. Ross, S.A. The Determination of Financial Structure: The Incentive-Signaling Approach. Bell J. Econ. 1977, 8, 23-40. [CrossRef]

32. Culp, C.L. Contingent Capital: Integrating Corporate Financing and Risk Management Decisions. J. Appl. Corp. Finan. 2002, 15, 46-56. [CrossRef]

33. Culp, C.L. The Art of Risk Management. Alternative Risk Transfer, Capital Structure and the Convergence of Insurance and Capital Markets; John Wiley \& Sons: New York, YN, USA, 2002.

34. Kloman, F.H. A Brief History of Risk Management. In Enterprise Risk Management. Today's Leading Research and Best Practices for Tomorrow's Executives; Fraser, J., Simkins, B.J., Eds.; John Wiley \& Sons: Hoboken, NJ, USA, 2010.

35. Dionne, G. Risk Management: History, Definition and Critique. Risk Manag. Insur. Rev. 2013, 16, $147-166$. [CrossRef]

36. Crockford, G.N. The Bibliography and History of Risk Management: Some Preliminary Observations. Geneva Pap. Risk Insur. 1982, 7, 169-179. [CrossRef]

37. Bromiley, P.; McShane, M.; Nair, A.; Rustambekov, E. Enterpirse Risk Management. Review, Critique and Research Directions. Long Range Plan. 2015, 48, 265-276. [CrossRef]

38. Purdy, G. ISO31000:2009—Setting a New Standard for Risk Management. Risk Anal. 2010, 30, 881-886. [CrossRef]

39. Falkner, E.M.; Hiebl, M.R. Risk management in SMEs: A systematic review of the available evidence. J. Risk Finan. 2015, 2015 16, 122-144. [CrossRef]

40. Bromiley, P.; Rau, D. A better way of managing major risks: Strategic risks management. IESE Insight 2016, 28, 15-22. [CrossRef]

41. Hopkin, P. Fundamentals of Risk Management: Understanding, Evaluating and Implementing Effective Risk Management, 3rd ed.; Kogan Page: London, UK, 2015.

42. Vaughan, E.; Vaughan, T. Fundamentals of Risk and Insurance; John Wiley \& Sons: Hoboken, NJ, USA, 2003.

43. Rejda, G.E. Principles of Risk Management and Insurance; Addison Wesley Longman: London, UK, 2001.

44. Dorfman, M. Introduction to Risk Management and Insurance; Pearson-Prentice Hall: Upper Saddle River, NJ, USA, 2005.

45. Mayers, D.; Smith, C.W. On the Corporate Demand for Insurance. J. Bus. 1982, 55, 281-296. [CrossRef]

46. Smith, C.W.; Stulz, R.M. The determinants of Firm's hedging policies. J. Finan. Quant. Anal. 1985, 20, $391-405$. [CrossRef]

47. MacMinn, R.D. Insurance and Corporate Risk Management. J. Risk Insur. 1987, 54, 658-677. [CrossRef]

48. Smithson, C.; Simkins, B.J. Does Risk Management Add Value? A Survey of the Evidence. J. Appl. Corp. Finan. 2005, 17, 8-17. [CrossRef]

49. Mikes, A.; Kaplan, R.S. When One Size Doesn't Fit All: Evolving Directions in the Research and Practice of Enterprise Risk Management. J. Appl. Corp. Finan. 2015, 27, 37-40. [CrossRef]

50. Gordon, L.A.; Loeb, M.P.; Tseng, C. Enterprise risk management and firm performance: A contingency perspective. J. Account. Public Policy 2009, 28, 301-327. [CrossRef]

51. McShane, M.K.; Nair, A.; Rustambekov, E. Does enterprise risk management increase firm value? J. Account. Audit. Finan. 2011, 24, 641-658. [CrossRef]

52. Whited, T.M. Debt, liquidity constraints, and corporate investment: Evidence from panel data. J. Finan. 1992, 47, 1425-1460. [CrossRef]

53. Fraser, J.R.; Simkins, B.J. The challenges of and solutions for implementing enterprise risk management. Bus. Horiz. 2016, 59, 689-698. [CrossRef]

54. Soppe, A. Sustainable Corporate Finance. J. Bus. Ethics 2004, 53, 213-224. [CrossRef]

55. Freeman, R.E. Strategic Management: A Stakeholder Approach; Pitman: Boston, MA, USA, 1984.

56. Donaldson, T.; Preston, L.E. The stakeholder theory of the corporation: Concepts, evidence, and implications. Acad. Manag. Rev. 1995, 20, 65-91. [CrossRef] 
57. Starik, M.; Marcus, A. Introduction to the Special Research Forum on the Management of Organizations in the Natural Environment: A Field Emerging From Multiple Paths, With Many Challenges Ahead. Acad. Manag. J. 2000, 43, 539-546.

58. Wong, A. Corporate sustainability through non-financial risk management. Corp. Govern. 2014, 14, 575-586. [CrossRef]

59. Anderson, D. The Critical Importance of Sustainability Risk Management. Risk Manag. 2006, 53, 66-74.

60. Anderson, D.; Anderson, K. Sustainability Risk Management. Risk Manag. Insur. Rev. 2009, 12, $25-38$. [CrossRef]

61. Margolis, J.D.; Walsh, J.P. Misery loves companies: rethinking social initiatives by business. Adm. Sci. Q. 2003, 48, 268-305. [CrossRef]

62. Pescaroli, G.; Alexander, D. A definition of cascading disasters and cascading effects: Going beyond the "toppling dominos" metaphor. Davos 2015, 2, 58-67.

63. Houdet, J.; Germaneau, C. The Financial Impacts of BP's Response to the Deepwater Horizon oil Spill. Synergis, Case Study 01-2011. Available online: http:/ / synergiz.fr/wp-content/uploads/2011/04/Casestudy-BP-gulf-oil.pdf (accessed on 15 December 2018).

64. Amadeo, K. BP Gulf Oil Spill Economic Impact. The Balance. 2018. Available online: https://www. thebalance.com/bp-gulf-oil-spill-facts-economic-impact-3306212 (accessed on 15 December 2018).

65. Flowler, J.T. Deepwater Horizon: A Lesson in Risk Analysis, Emergency and Disaster Management Digest. 2017. Available online: https:/ / edmdigest.com/news/deepwater-horizon-lesson-risk-analysis/ (accessed on 15 December 2018).

66. Norse, E.A.; Amos, J. Impacts, Perception, and Policy Implications of the Deepwater Horizon Oil and Gas. Disaster; Environmental Law Reporter, Environmental Law Institute: Washington, DC, USA, 2010; Available online: http:/ / www.ourenergypolicy.org/wp-content/uploads/2013/08/Norse-and-Amos-2010.pdf (accessed on 15 December 2018).

67. Technical analysis: Deepwater Horizon Accident Investigaton Report, 2010, Executive Summary. Available online: https:/ / www.bp.com/content/dam/bp/pdf/sustainability/issue-reports/Deepwater_Horizon_ Accident_Investigation_Report_Executive_summary.pdf (accessed on 15 December 2018).

68. Lipscy, P.; Kushida, K.; Incerti, T. The Fukushima Disaster and Japan's Nuclear Plant Vulnerability in Comparative Perspective. Environ. Sci. Technol. 2013, 47, 6082-6088. [CrossRef]

69. Hatamura, Y.; Abe, S.; Fuchigami, M.; Kasahara, N.; Lino, K. Fukushima-A complex study The 2011 Fukushima Nuclear Power Plant Accident. How and Why It Happened; Woodhead Publishing: Cambridge, UK, 2015.

70. Hollangel, E.; Fujita, Y. The Fukushima disaster-Systemic failures and the lack of resilience. Nucl. Eng. Technol. 2011, 45, 13-20. [CrossRef]

71. Srinivasan, T.N.; Gopi Rethirnaaj, T.S. Fukushima and thereafter: Reassessment of risks of nuclear power. Energy Policy 2013, 52, 726-736. [CrossRef]

72. Holzheu, T.; Karl, K.; Raturi, M. The Picture of Art; Sigma No. 1/2003; Swiss Re: Zurich, Switzerland, 2003.

73. Hartwig, R.P.; Wilkinson, C. An Overview of Alternative Risk Transfer Market. In Handbook of International Insurance. Between Global Dynamics and Local Contingencies; Cummins, J.D., Vernard, B., Eds.; Springer: New York, NY, USA, 2007.

74. Cummins, D.; Weiss, M.A. Convergence of insurance and financial markets: Hybrid and securitized risk transfer solutions. J. Risk Insur. 2009, 76, 493-545. [CrossRef]

75. Outreville, J.F. Theory and Practice of Insurance; Kluwer Academic Publishers: London, UK, 1998.

76. Williams, C.A.; Heins, R.M. Risk Management and Insurance; McGraw-Hill: New York, NY, USA, 1989.

77. Weber, E.J. A short history of Derivative Security Markets. The University of Western Australia Discussion Paper 08.10. 2008. Available online: http:/ / www.law.uwa.edu.au/_data/assets/pdf_file/0003/94260/08_ 10_Weber.pdf (accessed on 15 December 2018).

78. Watson, D.; Head, A. Corporate Finance. Principles and Practice; Pearson Education: Harlow, UK, 2001.

79. Bennett, D. Managing Foreign Exchange Risk; Ptitman Publishing: London, UK, 1997.

80. Strauss, J. The Definitive Guide to Captive Insurance Companies. What Every Small Business Owner Needs to Know About Creating and Implementing a Captive; Author House: Bloomington, UK, 2011.

81. Adkisson, J.D. Adkisson's Captive Insurance Companies. An. Introduction to Captives, Closely-Held Insurance Companies and Risk Retention Groups; iUniverse: New York, NY, USA, 2006. 
82. Kloman, H.F.; Rosenbaum, D.H. The Captive Insurance Phenomenon: A Cautionary Tale? Geneva Pap. Risk Insur. 1982, 7, 129-151. [CrossRef]

83. Banks, E. Alternative Risk Transfer. Integrated Risk Management through Insurance, Reinsurance and the Capital Markets; John Wiley \& Sons: Chichester, NH, USA, 2004.

84. Culp, C.; Heaton, B. Uses and Abuses of Finite Risk Reinsurance. J. Appl. Corp. Finan. 2005, 17, $18-31$. [CrossRef]

85. Carter, R.; Lucas, L.; Ralph, N. Reinsurance; Reactions Publishing Group in association with Guy Carpenter \& Company: London, UK, 2000.

86. Baur, E.; Schanz, K. Alternative Risk Transfer (ART) for Corporations: A Passing Fashion or Risk Management for the 21st Century? Sigma 2/1999; Swiss Re: Zurich, Switzerland, 1999.

87. Harrington, S.E.; Niechaus, G.; Risko, K.J. Enterprise Risk Management: The Case of United Grain Growers. J. Appl. Corp. Finan. 2002, 14, 71-81. [CrossRef]

88. Hagedorn, D.; Heigl, C.; Muller, A.; Seidler, G. Choice of Triggers. In The Handbook of Insurance-Linked Securities; Barrieu, P., Albertini, L., Eds.; John Wiley \& Sons: Chichester, NH, USA, 2009; pp. 37-48.

89. Frey, A.; Kirova, M.; Shmidt, C. The Role of Indices in Transferring Risks to the Capital Markets; Sigma 4/2009; Swiss Re: Zurich, Switzerland, 2009.

90. ARTEMIS database. Available online: http://www.artemis.bm/deal_directory/ (accessed on 15 December 2018).

91. Bourgeois, L.J. III. On the Measurement of Organizational Slack. Acad. Manag. Rev. 1981, 6, 29-39. [CrossRef]

92. Kim, H.; Kim, H.; Lee, P.M. Ownership structure and the relationship between financial slack and R\&D investments: Evidence from Korean Firms. Organ. Sci. 2008, 19, 404-418.

93. Zhong, H. The Relationship between Slack Resources and Performance: An Empirical Study from China. Int. J. Mod. Educ. Comput. Sci. 2011, 1, 1-8. [CrossRef]

94. Opler, T.; Pinkowitz, L.; Stulz, R.; Williamson, R. The determinants and implications of corporate cash holdings. J. Finan. Econ. 1999, 52, 3-46. [CrossRef]

95. Almeida, H.; Campello, M.; Weisbach, M.S. Corporate demand for liquidity. 2002. Available online: https:/ / www.nber.org/papers/w9253 (accessed on 15 December 2018).

96. Laffranchini, G.; Braun, M. Slack in family firms: Evidence from Italy (2006-2010). J. Fam. Bus. Manag. 2004, 4, 171-193. [CrossRef]

97. Modigliani, F.; Miller, M.H. The Cost of Capital, Corporate Finance and the Theory of Investment. Am. Econ. Rev. 1958, 48, 261-297.

98. Ehrhardt, M.C.; Brigham, E.F. Corporate Finance. A Focused Approach; South Western CENGAGE Learning: Mason, OH, USA, 2009.

(C) 2019 by the author. Licensee MDPI, Basel, Switzerland. This article is an open access article distributed under the terms and conditions of the Creative Commons Attribution (CC BY) license (http:// creativecommons.org/licenses/by/4.0/). 